\title{
Larva migrans in Votuporanga, São Paulo, Brazil: Where does the danger hide?
}

\author{
Larva migrans em Votuporanga, SP, Brazil: Onde se esconde o perigo? \\ Giane Serafim da Silva1* (D); Frederico Cardoso Ferreira²; Daiane Mompean Romera3; Vando Edésio Soares; \\ Marcos Roberto Bonuti ${ }^{5}$ \\ ${ }^{1}$ Laboratório de Parasitologia Animal de Votuporanga, Instituto Biológico, Agência Paulista de Tecnologia dos Agronegócios-APTA, \\ Secretaria de Agricultura e Abastecimento, Votuporanga, SP, Brasi \\ ${ }^{2}$ Santa Casa de Misericórdia de São José do Rio Preto, São José do Rio Preto, SP, Brasil \\ ${ }^{3}$ Centro de Seringueira e Sistemas Agroflorestais, Instituto Agronômico de Campinas, Agência Paulista de Tecnologia dos \\ Agronegócios-APTA, Secretaria de Agricultura e Abastecimento, Votuporanga, SP, Brasil \\ ${ }^{4}$ Universidade Brasil, Descalvado, SP, Brasil \\ ${ }^{5}$ Universidade Brasil, Fernandópolis, SP, Brasi
}

How to cite: Silva GS, Ferreira FC, Romera DM, Soares VE, Bonuti MR. Larva migrans in Votuporanga, São Paulo, Brazil: Where does the danger hide? Braz J Vet Parasito/ 2020; 29(3): e004920. https://doi.org/10.1590/S1984-29612020075

\begin{abstract}
Soil samples collected near municipal schools (public/EMEl and private/EPEI schools), clubs (CLB), public squares (PS) and residential condominiums (CND) and samples of animal faeces from the Zoonosis Control Centre (CCZ) of the municipality of Votuporanga/SP were analysed using the Baermann method for the detection of zoonotic helminth larvae. The prevalence rates of the nematode genera identified were determined, and the results were compared using Fisher's exact and chi-square frequency tests. Information about cases of larvae migrans in the population were collected from the Family Health Units and the private health plans. All sites were positive for Ancylostoma spp. and, with the exception of EPEls and dog faeces, for Strongyloides spp. The prevalence of Ancylostoma spp. was $87.5 \%$ for CND samples, $74.29 \%$ for EMIEs, $63.64 \%$ for CLB, 61.76\% for PS and $64.29 \%$ for dog's and $42.86 \%$ for cats at CCZ. The prevalence of Strongyloides spp. ranged from $14.29 \%$ (cats/CCZ) to $41.18 \%$ (PS). Cases of cutaneous larva migrans were reported during interviews. Thus, from the public health perspective, the risk of individuals that frequent recreational areas in the municipality, especially children, to be infected by helminth larvae is noteworthy, indicating the need to develop policies aimed at controlling this important zoonosis.
\end{abstract}

Keywords: Larva migrans, Ancylostoma, Strongyloides, soil.

\section{Resumo}

Amostras de solo colhidas em escolas municipais (ensino público/EMEl e privado/EPEI), clubes (CLB), praças públicas (PP), condomínios residenciais (CND) e de fezes de animais do Centro de Controle de Zoonoses (CCZ) do município de Votuporanga/SP, foram submetidas ao método Baermann para detecção de larvas de helmintos zoonóticos. Foram determinadas as taxas de prevalência dos nematódeos identificados, e os resultados confrontados pelos testes Exato de Fisher e Qui-quadrado. Atendimentos de casos de larvas migrans na população foram levantados em entrevistas realizadas em Unidades de Saúde da Família e em planos de saúde privados. Todos os locais apresentaram positividade para Ancylostoma spp. e, com exceção de EPEls e de fezes caninas, para Strongyloides spp. Prevalência de Ancylostoma spp. foi verificada em amostras de CNDs (87,50\%), EMEls (74,29\%), CLBs (63,64\%), PPs (61,76\%) e em fezes de cães e gatos do CCZ (64,29\% e 42,86\%, respectivamente). As prevalências de Strongyloides spp. variaram de 14,29\% (gatos/CCZ) a 41,18\% (PP). Atendimentos de casos de larva migrans cutânea foram relatados nas entrevistas. Portanto, ressalta-se o risco de frequentadores de áreas de lazer do município, especialmente crianças, de adquirirem infecção por larvas de helmintos, indicando a necessidade da elaboração de propostas de políticas voltadas ao controle dessa importante zoonose.

Palavras-chave: Larva migrans, Ancylostoma, Strongyloides, solo. 


\section{Introduction}

The nematodes Ancylostoma spp., Toxocara spp. and Strongyloides stercoralis, parasites of dogs and cats, are considered important zoonotic agents. They represent a serious problem for public health because humans are an accidental host, who become infected by direct contact with infected animals either by active penetration of the larvae through the skin or by ingesting eggs present on soil, fomites, hands, food and water (Peruca et al., 2009; Ganesh \& Cruz, 2011; Dantas-Torres \& Otranto, 2014; Chen et al., 2018).

Larvae of Ancylostoma braziliensis, the main species responsible for the "cutaneous larva migrans" pathology, popularly known is Brazil as "bicho geográfico", penetrate and migrate through the skin in an irregular pattern, causing pruritic, erythaematous and serpiginous dermal lesions (Robles \& Habashy, 2018). In turn, when ingested, Toxocara spp. eggs can cause "visceral", "ocular", "neurological" or "asymptomatic" larva migrans, which can affect various organs, such as the liver, heart, lungs, kidneys, muscles, eyes and brain, leading to a set of clinical symptoms with serious health consequences (Carvalho \& Rocha, 2011; Chen et al., 2018;). Infection by Strongyloides stercoralis, which have a cardiopulmonary development cycle, occurs through skin penetration of infective larvae present in soil, faeces or water.

Cases of larva migrans in humans have been reported in several countries, including Brazil (Jackson et al., 2006; Del Giudice et al., 2019; Reis et al., 2019; Rodrigues et al., 2019). The infection of dogs and cats by the nematodes Ancylostoma spp., Toxocara spp. and Strongyloides spp. has also been reported (Bresciani et al., 2008; Ferreira et al., 2016; Oliveira-Arbex et al., 2017).

The growing number of domestic, peridomestic and stray dogs, combined with the easy access of these animals to recreational sites, can significantly increase soil contamination by potentially zoonotic helminths, constituting a potential risk for individuals frequenting such sites, especially for children, as reported by Chen et al. (2018) and Evaristo et al. (2019).

Although there has been an increase in the number of studies on this topic in the last two decades, according to Chen et al. (2018), toxocariasis remains a public health challenge worldwide, leading to the need for continuous surveillance.

The detection of eggs in the external environment is internationally recognized as an important indicator of zoonotic contamination (Błaszkowska et al., 2015). In this sense, the presence of eggs and larvae of the nematodes Ancylostoma spp., Toxocara spp. and Strongyloides spp. in sands or soils of recreational areas located in children's playgrounds, public parks and schools is a risk to which the population is subjected to in different regions of Brazil (Nunes et al., 2000; Cassenote et al., 2011; Chen et al., 2018; Gonçalves \& Paludo, 2018; Monteiro et al., 2018; Robles \& Habashy, 2018; Padilha et al., 2019; Rocha et al., 2019).

Given the zoonotic importance of helminth parasites of dogs and cats and the relevance of the diagnosis of the situation in the country, seeking to support the development of control programmes and the implementation of effective public health measures, the present study aimed to evaluate soil samples (sand/soil) from recreational areas frequented by children and samples of faeces of dogs and cats from Zoonotic Control Centre, in the municipality of Votuporanga, state of São Paulo, Brazil, for the presence of Ancylostoma spp. and Strongyloides spp larvae. Information about cases of larval migrans in the municipality were also obtained.

\section{Materials and methods}

\section{Study Site}

The study was conducted in the municipality of Votuporanga $\left(20^{\circ} 25^{\prime} 06^{\prime \prime}\right.$ south latitude and $49^{\circ} 58^{\prime} 39^{\prime \prime}$ west longitude, with smooth relief and altitude of $525 \mathrm{~m}$ ), in the northwest region of the state of São Paulo, Brazil, with an estimated population of 94,547 inhabitants in 2019 (IBGE, 2019). According to Koeppen, this region has an aw climate, with a rainy season in the summer, followed by a mild and dry winter; the average annual rainfall is approximately $1,500 \mathrm{~mm}$.

\section{Samples}

A total of 123 sand/soil samples were collected from recreational areas frequented by children, located near schools, clubs, condominiums and parks in the city, and 21 faecal samples from dogs and cats housed in the Zoonosis Control Centre (CCZ, for its acronym in Portuguese). Through the Department of Education and Urban Development of the municipality, nine municipal preschools (EMEls $=35$ samples) and nine public squares (PSs = 34 samples) 
were selected that had recreational areas on their premises. Three private preschools (EPEls $=24$ samples), two member-only recreational clubs, one of them a country club (CLBs $=22$ samples), and the playground of two private residential condominiums (CNDs $=08$ samples) were also included in the study.

Sand and/or soil samples were collected using a PVC pipe at approximately eight centimetres depth relative to the surface, preferably in moist and shaded areas $\left(01\right.$ sample $\left./ 5 \mathrm{~m}^{2}\right)$. Faecal samples from dogs ( 14 samples) and cats (07 samples) housed in the CCZ of the municipality were collected in the morning before cleaning the area, where the animals were kept in individual or collective pens.

All samples were duly stored, labelled and transported to the Laboratory of Animal Parasitology of Votuporanga at the Biological Institute/APTA.

\section{Parasitological procedures}

All samples were screened for nematode larvae using the Baermann method and optical microscopy was used to identify the larvae according to Ueno \& Gonçalves (1998). The prevalence rates of the identified nematode genera were calculated (Wagner, 1998). Helminth eggs and protozoan oocysts were also investigated in the faecal samples of the animals from the Zoonosis Control Center using the technique of Gordon \& Whitlock (1939).

\section{Survey of the Occurrence of larva migrans in the municipality}

A survey of cases of cutaneous and visceral larva migrans was conducted through interviews in nine Family Health Units (USFs, for its acronym in Portuguese), representative of the districts of the municipality, according to the Department of Urban Development of the municipality and in two private health plans. The interviews were conducted in person when the responsible for the USF or for the health plans was asked about registers of larva migrans cases in the retrospective period of one year (yes or no). Nine pediatricians and/or dermatologists were also interviewed in their private offices, about medical care of larva migrans cases.

\section{Statistical analysis}

The results were compared using Fisher's exact test and chi-square at the 95\% confidence level (StatSoft, Inc., 2014). The study was approved by the Ethics Committee of the Centro Universitário de Votuporanga - UNIFEV/SP (Process Number 1,443,306) and conducted within the applicable ethical standards.

\section{Results}

All sampled sites were positive for Ancylostoma spp. larvae and, except for EPEls and dog faeces, for Strongyloides spp. larvae. The prevalence of Ancylostoma spp. $(61.11 \%)$ was significantly higher $(\mathrm{P}<0.05)$ than that of Strongyloides spp. (22.92\%) (Table 1).

Table 1. Results of the faecal parasitology tests performed with samples collected in the municipality of Votuporanga, SP, Brazil. Multiple comparisons of prevalence at different sites.

\begin{tabular}{|c|c|c|c|}
\hline \multirow{2}{*}{ Local/Samples } & & \multicolumn{2}{|c|}{ Helminths (larvae) / Prevalence(\%)* } \\
\hline & & Ancylostoma spp. & Strongyloides spp. \\
\hline Municipal Preschools I (EMEI) & 35 & $74.29 \mathrm{Aa}$ & $28.57 \mathrm{Ab}$ \\
\hline Private Preschools (EPEI) & 24 & $33.33 \mathrm{Ba}$ & $0.00 \mathrm{Cb}$ \\
\hline Public Squares (PP) & 34 & $61.76 \mathrm{Aa}$ & 41.18 Aa \\
\hline Private Residential Condominiums (CND) & 8 & $87.50 \mathrm{Aa}$ & $25.00 \mathrm{ABCb}$ \\
\hline Member-only Recreational Clubs (CLB) & 22 & $63.64 \mathrm{Aa}$ & $27.27 \mathrm{ABb}$ \\
\hline Zoonosis Control Centre (CCZ-dog feces) & 14 & $64.29 \mathrm{Aa}$ & $0.00 \mathrm{Cb}$ \\
\hline Zoonosis Control Centre (CCZ-cats feces) & 7 & $42.86 \mathrm{ABa}$ & $14.29 \mathrm{ABCa}$ \\
\hline TOTAL & 144 & 61.11 a & $22.92 \mathrm{~b}$ \\
\hline
\end{tabular}

\footnotetext{
*: Values followed by the same letters, uppercase in the column and lowercase in the row, do not differ by Fisher's Exact test (Frequencies less
} than 5) or Chi-Square (Frequencies equal to or greater than 5) $(p \geq 0.05)$ 
There was no positivity for Strongyloides spp. in soil samples of EPIs or in fecal samples of dog from the CCZ. The prevalence rates in soil samples of PP, EMEls, CLBs, CNDs and in cat faeces $(41.18 \%, 28.57 \%, 27.27 \%$ and $25.00 \%$, respectively) was not statistically different ( $P>0.05$ ) (Table 1 ).

Regarding the sites sampled, the highest prevalence rates of Ancylostoma spp. were observed in samples from CNDs (87.50\%) and EMEIs (74.29\%), followed by CLBs (63.64\%), PSs (61, 76\%) and the CCZ (dogs: $64.29 \%$ and cats $42.86 \%)$, with no significant differences $(P>0.05)$ between these sites; however, the prevalence observed in samples from EPEIs $(33.33 \%)$ was significantly lower $(\mathrm{P}<0.05)$ than the other sites, except for the cat faeces prevalence (Table 1).

EMEls had the second highest prevalence rate of Ancylostoma sp. (74.29\%), with $88.89 \%$ of schools exhibiting positive results. A child with lesions characteristic of cutaneous larva migrans was identified in one of the EMEls during sampling (Figure 1). Strongyloides spp. presented prevalence rates ranging from $14.29 \%$ (cat faeces/CCZ) to $41.18 \%$ (PSs), with no significant differences ( $P>0.05$ ) between the results of sites positive for this nematode (Table 1). Although positive, the values for CNDs (25.00\%) and cat faeces/CCZ (14.29\%) were also not significantly different $(P>0.05)$ from the sites that did not show contamination (EPEIs and dog faeces/CCZ). Samples from the two studied clubs showed a predominance of Ancylostoma spp. (63.64\%) and Strongyloides spp. (27.27\%), and the highest number of positive samples was observed in the country club, which has a larger open area that animals can easily access.

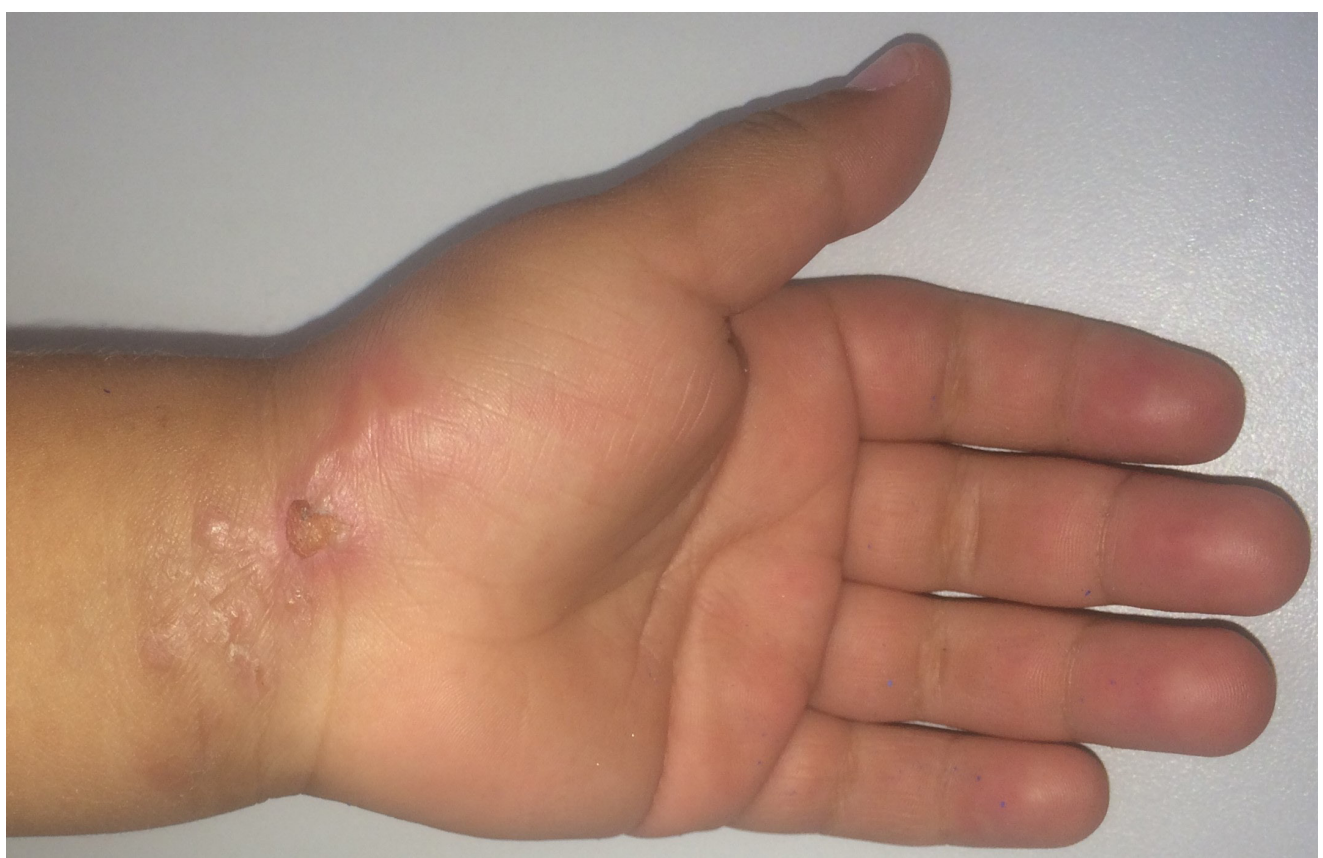

Figure 1. Characteristics lesions of cutaneous larva migrans observed on a student attending a municipal preschool during the study. Votuporanga, SP, Brazil.

Tests of faecal samples from animals housed in the CCZ revealed Ancylostoma spp. larvae in dog and cat faeces (64.29\% and $42.86 \%$, respectively), without significant differences ( $P>0.05)$ between them. Only cats were parasitized by Strongyloides spp., but no significant differences $(P>0.05)$ relative to the other sites positive for the nematode or even relative to the sites negative for the nematode were observed.

Cases of cutaneous larva migrans were reported in all of the interviewed USFs (Table 2). Only one private health plan reported cases of such pathology. Fifty-nine cases of cutaneous larva migrans were reported by the doctors interviewed in their private offices.

No cases of visceral larva migrans were reported by the USFs, by the private health plans or by interviewed doctors.

Toxocara spp eggs and protozoan oocysts were diagnosed in the faecal samples of dogs and cats from Zoonosis Control Center. 
Table 2. Report of cases of cutaneous larva migrans (CLM) registered at the Family Health Units (USFs) and at private health plans of Votuporanga, SP, Brazil.

\begin{tabular}{|c|c|c|}
\hline $\begin{array}{l}\text { Family Health Units (USF) - } \\
\text { PrivateHealth Plans (PSP) - Doctors }\end{array}$ & $\begin{array}{l}\text { Reported cases of cutaneous larva } \\
\text { migrans }\end{array}$ & Coverage \\
\hline USF 1 & yes & EMEI \\
\hline USF 2 & yes & EMEI, PP, CR \\
\hline USF 3 & yes & EMEl; PP \\
\hline USF 4 & yes & EMEl; PP \\
\hline USF 5 & yes & EMEl; EPEl; PP; CR \\
\hline USF 6 & yes & EMEI - V \\
\hline USF 7 & yes & EMEI - III \\
\hline USF 8 & yes & EMEl; PP \\
\hline USF 9 & yes & EMEl; EPEI; PP \\
\hline PSP 1 & yes & ---------- \\
\hline PSP 2 & no & \\
\hline $\begin{array}{l}\text { PEDIATRICIANS AND/OR } \\
\text { DERMATOLOGISTS }\end{array}$ & 59 cases & --------- \\
\hline
\end{tabular}

\section{Discussion}

The positivity for Ancylostoma spp. larvae at all sites sampled and for Strongyloides sp. larvae at most sites highlights the challenge to public health and the need for continuous surveillance of zoonoses (Peruca et al., 2009; Chen et al., 2018).

Although the prevalence of Strongyloides spp. $(22.92 \%)$ has been significantly lower $(P<0.05)$ than the Ancylostoma spp (61.11\%), attention should be paid to its potential as a zoonotic agent, as well as to its presence in the municipality, which has already been reported by Malta (2005), who diagnosed S. stercoralis in children attending day care centers of the city of Votuporanga/SP.

The higher prevalence of Ancylostoma spp. (87.50\%) found in samples from the CND playgrounds was unexpected because these areas are delimited by walls and have controlled entries, which should contribute to this zoonosis prevention, as mentioned by Rocha et al. (2019). Moreover, because CNDs represent medium- and high-standard residences, it is expected that the pets that frequent the internal areas have been dewormed and/or have regularly seen a veterinarian. These findings emphasize the need of health education to the population about zoonoses transmitted by pets and other owned animals (Domingues et al., 2015).

The number of municipal schools that were positive for Ancylostoma spp. (88.89\% of the EMEls) and the high prevalence found (74.29\%) draw attention to the danger of children contracting cutaneous larva migrans from their environment, a risk that was confirmed when a student with lesions characteristic of cutaneous larva migrans was identified during sample collection at one of the schools. These results were higher than those found by Nunes et al. (2000), in sand samples from municipal preschools in Araçatuba, also located at the northwest region of the state SP (46.4\% of schools with positivity), and by Cassenote et al. (2011), in Fernandópolis, where 6.1\% positivity for geohelminth eggs was observed in municipal preschool sandboxes. However, results close to those found in the present study were observed in the city of São Paulo, where $84.3 \%$ of samples from preschool recreational areas were positive for Toxocara spp. and/or Ancylostoma spp. (Maeda et al., 2010).

The fact that a greater number of positive samples was observed in the country club, which has a large open area and stray cats and dogs in the area, indicates that the easy access of peridomestic and stray dogs to recreational areas can significantly increase soil contamination by potentially zoonotic helminths (Cassenote et al., 2011). In addition, reports on social networks of the occurrence of cases of cutaneous larva migrans in children attending the site were also found during the study. Although the club's board had already changed the park's sand, the environment became re-infested in a short period of time. Thus, in addition to replacing the sand, it was 
recommended to prevent the entry of dogs and cats into the area. However, this measure will only be effective with the implementation of a public policy focused on the control of stray animals in the city, together with society's awareness regarding the responsible ownership of animals, as previously mentioned.

In the case of open sites, the possibility of the population being contaminated by Ancylostoma spp. in public squares was also recorded in Rio Grande do Sul by Evaristo et al. (2019), where a prevalence of $61.11 \%$ was observed, a result similar to that shown in the present study for PS samples $(61.76 \%)$.

The high prevalence of Ancylostoma spp. in dogs housed in the CCZ (64.29\%) was also reported by Bresciani et al. (2008) in dogs surrendered to the CCZ in the same region of the state (75.38\%).

Considering that the dogs and cats housed in the CCZ are stray animals which, before being captured, circulated freely through the city, with access to recreational areas of parks, clubs and even schools, the positivity of parasitism in faeces from these animals is consistent with the results obtained for samples collected elsewhere.

The results reveal, from the public health perspective, the risk of people, especially children, frequenting recreational areas in the municipality of Votuporanga, SP, Brazil, being infected by Ancylostoma spp. and Strongyloides spp., emphasizing the need to develop public policies aimed at controlling this important zoonosis.

\section{Acknowledgements}

The authors are grateful to CNPq for the financial support (Process: 138618/2015-1).

\section{References}

Błaszkowska J, Góralska K, Wójcik A, Kurnatowski P, Szwabe K. Presence of Toxocara spp. eggs in children's recreation areas with varying degrees of access for animals. Ann Agric Environ Med 2015; 22(1): 23-27. http://dx.doi.org/10.5604/12321966.1141363. PMid:25780822.

Bresciani KDS, Ishizaki MN, Kaneto CN, Montano TRP, Perri SHV, Vasconcelos RO, et al. Frequência e intensidade parasitária de helmintos gastrintestinais em cães na área urbana do Município de Araçatuba, SP. Ars Vet 2008; 24(3): 181-185. http://dx.doi. org/10.15361/2175-0106.2008v24n3p181-185.

Carvalho EA, Rocha RL. Toxocariasis: visceral larva migrans in children. J Pediatr (Rio J) 2011; 87(2): 100-110. http://dx.doi. org/10.2223/JPED.2074. PMid:21503372.

Cassenote AJF, Pinto Neto JM, Lima-Castelani ARA, Ferreira AW. Contaminação do solo por ovos de geo-helmintos com potencial zoonótico na municipalidade de Fernandópolis, Estado de São Paulo, entre 2007 e 2008. Rev Soc Bras Med Trop 2011; 44(3): 371374. http://dx.doi.org/10.1590/S0037-86822011005000026. PMid:21552740.

Chen J, Liu Q, Liu GH, Zheng WB, Hong SJ, Sugiyama H, et al. Toxocariasis: a silent threat with a progressive public health impact. Infect Dis Poverty 2018; 7(1): 59. http://dx.doi.org/10.1186/s40249-018-0437-0. PMid:29895324.

Dantas-Torres F, Otranto D. Dogs, cats, parasites, and humans in Brazil: opening the black box. Parasit Vectors 2014; 7(1): 22. http://dx.doi.org/10.1186/1756-3305-7-22. PMid:24423244.

Del Giudice P, Hakimi S, Vandenbos F, Magana C, Hubiche T. Autochthonous Cutaneous Larva Migrans in France and Europe. Acta Derm Venereo/ 2019; 99(9): 805-808. http://dx.doi.org/10.2340/00015555-3217. PMid:31073620.

Domingues LR, Cesar JA, Fassa AG, Domingues MR. Guarda responsável de animais de estimação na área urbana do município de Pelotas, RS, Brasil. Cien Saude Colet 2015; 20(1): 185-192. http://dx.doi.org/10.1590/1413-81232014201.19632013. PMid:25650612.

Evaristo TA, Lignon JS, Pellegrin TG, Camassola JL, Ferraz A, Leão MS, et al. Frequência de Ancylostoma spp. em amostras fecais ambientais nas praças públicas de Pedro Osório, RS. Pubvet 2019; 13(4): 1-7. http://dx.doi.org/10.31533/pubvet.v13n4a315.1-7.

Ferreira JIGS, Pena HFJ, Azevedo SS, Labruna MB, Gennari SM. Occurrences of gastrointestinal parasites in fecal samples from domestic dogs in São Paulo, SP, Brazil. Braz J Vet Parasitol 2016; 25(4): 435-440. http://dx.doi.org/10.1590/s1984-29612016081. PMid:27925072.

Ganesh S, Cruz RJ Jr. Strongyloidiasis: A multifaceted disease. J Gastroenterol Hepatol 2011; 7(3): 194-196. PMid:21528049.

Gonçalves GV, Paludo CA. Ocorrência de parasitas zoonóticos no solo de praças públicas da cidade de Bento Gonçalves, Rio Grande do Sul. Revista Uningá 2018; 55(2): 72-80.

Gordon HML, Whitlock AV. A new technique for counting nematode eggs in sheep feces. J Counc Sci Ind Res 1939; 12(1): 50-52.

Instituto Brasileiro de Geografia e Estatística - IBGE. Panorama da população estimada para o município de Votuporanga [online]. Rio de Janeiro: IBGE; 2019 [cited 2019 Nov 26]. Available from: https://cidades.ibge.gov.br/brasil/sp/votuporanga/panorama 
Jackson A, Heukelbach J, Calheiros CML, Soares VJ, Harms G, Feldmeier H. A study in a community in Brazil in which cutaneous larva migrans is endemic. Clin Infect Dis 2006; 43(2): e13-e18. http://dx.doi.org/10.1086/505221. PMid:16779735.

Maeda MM, Almeida AA, Cortez I, Oliveira ML, Yai LEO. Ocorrência de larva migrans em amostras de solo de áreas de lazer dos Centros de Educação Infantil (CEI) conveniados do município de São Paulo. Rev Saúde 2010; 4(1): 79.

Malta RCG. Estudo epidemiológico dos parasitas intestinais em crianças no município de Votuporanga - SP. [dissertação]. Campinas: Universidade Estadual de Campinas; 2005.

Monteiro MMC, Gonçalves CA, Rodrigues AA, Oliveira RC, Lima JAS, Avelar JB, et al. Ocorrência de potenciais agentes causadores de larva migrans em parques e praças públicas em Aparecida de Goiânia, Goiás, Brasil. J Neotrop Biol 2018; 15(2): 73-77. http:// dx.doi.org/10.5216/rbn.v15i2.51493.

Nunes CM, Pena FC, Negrelli GB, Anjo CGS, Nakano MM, Stobbe NS. Ocorrência de larva migrans na areia de áreas de lazer das escolas municipais de ensino infantil, Araçatuba, SP, Brasil. Rev Saude Publica 2000; 34(6): 656-658. http://dx.doi.org/10.1590/ S0034-89102000000600015. PMid:11175613.

Oliveira-Arbex A, David E, Oliveira-Sequeira T, Katagiri S, Coradi S, Guimarães S. Molecular identification of Ancylostoma species from dogs and an assessment of zoonotic risk in low-income households, São Paulo State, Brazil. J Helminthol 2017; 91(1): 14-19. http://dx.doi.org/10.1017/S0022149X15001145. PMid:26752269.

Padilha AS, Sperotto RL, Portella AF, Henn A. Análise da ocorrência de parasitos com potencial zoonótico no solo de escolas municipais infantis em dois municípios do Rio Grande do Sul. Clin Biomed Res 2019; 39(1): 9-14. http://dx.doi.org/10.4322/23579730.85692.

Peruca LCB, Langoni H, Lucheis SB. Larva migrans visceral e cutânea como zoonoses: revisão de Literatura. Vet Zootec 2009; 16(4): 601-616.

Reis PHB, Ramos AP, Neto RMB, Duarte MB, Duarte LF, de Souza MCA. Resolutividade no tratamento de larva migrans por equipe com visão ampliada de saúde: relato de caso. Rev Saúde 2019; 10(1): 27-31. http://dx.doi.org/10.21727/rs.v10i02.1534.

Robles TD, Habashy J. Cutaneous Larva Migrans [online]. New York: Medscape; 2018 [cited 2019 Nov 14]. Available from: https:// emedicine.medscape.com/article/1108784-print

Rocha MJ, Weber DM, Costa JP. Prevalência de larvas migrans em solos de parques públicos da cidade de Redenção, estado do Pará, Brasil. Rev Pan-Amaz Saude 2019; 10(0): e201901607. http://dx.doi.org/10.5123/S2176-6223201901607.

Rodrigues FT, Silva PGA, D'Acri AM, Martins CJ. An exuberant case of cutaneous larva migrans. J Port Soc Dermatol Venereol 2019; 77(2): 161-164. http://dx.doi.org/10.29021/spdv.77.2.1058.

StatSoft, Inc. STATISTICA (data analysis software system). version 12. [online]. St Tulsa: StatSoft; 2014 [cited 2019 Ago 4]. Available from: www.statsoft.com

Ueno H, Gonçalves PC. Manual para diagnóstico das helmintoses de ruminantes. Tokyo, Japan: International Cooperation Agency; 1998.

Wagner MB. Medindo a ocorrência da doença: prevalência ou incidência? J Pediatr 1998; 74: 157-162. 